\title{
PROSES KOMUNIKASI GURU BIMBINGAN KONSELING DALAM MENGATASI SISWA YANG BERMASALAH DALAM PROSES BELAJAR (Studi Kasus SMA Muhammadiyah 2 Yogyakarta)
}

\author{
Fungky Sofia Alwi \\ Program Pasca Sarjan Magister Studi Islam \\ Universitas Muhammadiyah Yogyakarta \\ E-mail: fungkyalwisofi@gmail.com
}

\begin{abstract}
Abstrak
Penelitian ini bertujuan: (1) Proses belajar siswa di SMA Muhammadiyah 2 Yogyakarta. (2) Proses komunikasi guru BK dalam mengatasi siswa bermasalah dalam proses belajar di SMA Muhammadiyah 2 Yogyakarta. Metode penelitian adalah kualitatif yang disampaikan dengan deskriptif. Penelitian menggunakan teknik purposive sampling, yaitu siswa kelas XI SMA Muhammadiyah 2 Yogyakarta angkatan tahun 2017-2018. Pengumpulan data dilakukan dengan interview, observasi, dokumentasi. Hasil penelitian ini: (1) Masalah dalam proses belajar siswa di SMA Muhammadiyah 2 Yogyakarta seperti: malas mengikuti pelajaran, tidak dapat konsentrasi saat mengikuti pelajaran, tertidur saat guru mata pelajaran menjelaskan materi, masalah keluarga, masalah antar teman, dan masalah yang lainnya. Guru mata pelajaran sudah berusaha untuk memberikan materi semaksimal mungkin. Guru BK telah melakukan fungsi layanan BK secara maksimal dalam konseling proses belajar siswa. (2) Proses komunikasi guru BK dalam mengatasi siswa bermasalah dalam proses belajar di SMA Muhammadiyah 2 Yogyakarta melalui: tahap persiapan, tahap pembentukan, dan tahap evaluasi.
\end{abstract}

Kata kunci: komunikasi, guru bk, proses belajar

\begin{abstract}
This study aims: (1) Student learning process in SMA Muhammadiyah 2 Yogyakarta. (2) The communication process of BK teachers in overcoming the problem students in the learning process in SMA Muhammadiyah 2 Yogyakarta. The research method is qualitative with descriptive. The research used purposive sampling technique, that is student of class XI SMA Muhammadiyah 2 Yogyakarta force year 2017-2018. Data collection is done by interview, observation, documentation. The results of this study are: (1) Problems in the learning process of students in SMA Muhammadiyah 2 Yogyakarta such as: lazy to follow lesson, unable to concentrate while studying, fall asleep when subject matter teacher explain matter, family problem, friend problem, and other problem. Subject teachers have tried to provide the maximum possible material. BK Teachers have done BK service function maximally in counseling student learning process. (2) The communication process of $B K$ teachers in addressing problematic students in the learning process at SMA Muhammadiyah 2 Yogyakarta through: preparation stage, formation stage, and evaluation phase.
\end{abstract}

Keywords: communication, teacher bk, learning process

Info Artikel

Diterima Maret 2018, disetujui April 2018, diterbitkan Juni 2018

Dipublikasikan Oleh: Program Studi Bimbingan dan Konseling 


\section{PENDAHULUAN}

Dalam proses pendidikan di sekolah, kehidupan siswa sangat dinamis dan berada dalam proses perkembangan, memiliki kebutuhan dan dinamika dalam interaksinya dengan lingkungannya. Proses perkembangan dipengaruhi oleh beberapa faktor baik dalam maupun luar. Bimbingan dan konseling (BK) merupakan salah satu unsur dari pendidikan yang harus ada di sekolah pada umumnya dan untuk meningkatkan mutu pendidikan yang ada di sekolah pada khususnya. Hal ini sangat relevan, karena pendidikan merupakan usaha sadar yang bertujuan untuk mengembangkan kepribadian dan potensi siswa termasuk bakat, minat, dan kemampuan.

Tujuan BK di sekolah adalah membantu siswa untuk mengembangkan pemahaman diri sesuai dengan kecakapan, minat, pribadi, hasil belajar serta kesempatan yang ada. Selain itu, juga membantu individu dalam penyesuaian diri terhadap diri dan lingkungan, serta mengembangkan kemampuan dan potensi yang dimiliki. Dengan demikian, individu yang dapat memahami pribadi dan kehidupannya akan menjamin hidup lebih kreatif danbahagia.

SMA Muhammadiyah 2 Yogyakarta merupakan salah satu SMA swasta yang tidak diragukan lagi keberadaannya. Permasalahan siswa di SMA Muhammadiyah 2 Yogyakarta tidak jauh berbeda dengan sekolah- sekolah lainnya. Sehingga terkadang masalah yang ada dapat menjadi penghambat dari proses pendidikan siswa dalam belajar. Dengan sarana prasarana dan tenaga pengajar profesional yang ada, berbagai masalah belajar yang timbul sehingga diperlukan kecakapan untuk mengatasi masalah belajar yang muncul.

Adapun gejala-gejala yang menjadikan siswa masuk dalam kategori siswa bermasalah seperti: suka menyendiri, terlambat masuk ke sekolah, membully teman, berkurangnya sikap sopan dan santun kepada orang lain, hiperaktif atau mencari perhatian orang lain, kurangnya motivasi belajar, dan prestasi belajar yang rendah.

Layanan BK di sekolah membantu siswa mencapai tugas perkembangan individu dengan baik. Adanya BK membantu siswa dalam melakukan aktifitas belajar sesuai dengan yang telah ditentukan. Teknik komunikasi BK ialah komunikasi interpersonal, dimana komunikasi lebih intens atau mendalam antara siswa dan guru bimbingan, tatap muka (face to face) yang memungkinkan untuk mudahnya terjalin hubungan diadik. Secara umum, pelaksanaan BK di sekolah bertujuan membantu siswa mengenal dan menerima diri, mengenal dan menerima lingkungan secara positif serta mampu mengambil keputusan sesuai dengan keadaan diri. Secara khusus, layanan BK bertujuan membantu siswa agar mencapai tujuan 
perkembangan yang meliputi aspek pribadi sosial, belajar, dan karir.

Komunikasi layanan

BK merupakan suatu proses komunikasi verbal dan non verbal antara konselor dan konseli yang memiliki tujuan untuk mencapai suatu kesepakatan berupa solusi terhadap masalah yang dihadapi sesorang, dimana cara tersebut harus dilaksanakan secara bertanggungjawab. Komunikasi BK merupakan wujud dari perhatian kita terhadap orang lain dengan maksud untuk membantu seseorang keluar dari masalahnya dan membuat orang tersebut berubah menjadi lebih baik.

Devito (dalam Alo Liliweri, 1997) memberikan lima ciri-ciri komunikasi antar pribadi, hal tersebut untuk memudahkan atau memperjelas pengertiannya, seperti: openess (keterbukaan); emphaty (empati); supportiveness (dukungan); positiveness (rasa positif); equality (kesamaan). Siswa yang memiliki permasalahan memerlukan BK agar rasa ketidakpuasan yang mengganggu dapat dikendalikan dan diarahkan. BK merupakan serangkaian program layanan yang diberikan oleh suatu lembaga pendidikan kepada peserta didik agar mereka mampu berkembang lebih baik dan lebih optimal. Adanya komunikasi yang efektif dari guru BK dan siswa memiliki harapan agar mampu memberikan motivasi kepada siswa untuk bergerak ke arah yang positif. Dengan komunikasi yang baik, siswa akan lebih terbuka serta dapat berinteraksi untuk menciptakan lingkungan sekolah yang aman dan nyaman.

Secara praktis, penelitian dapat menemukan informasi tentang bagaimana proses komunikasi guru BK dalam mengatasi masalah yang terjadi pada proses belajar hingga penyelesaian masalah belajar. Peneliti ingin mengumpulkan informasi tentang bagaimana para guru menggunakan dan mengembangkan keterampilannya dalam berkomunikasi dengan para siswa dalam mengatasi masalah belajar agar para peserta didik menunjukkan prestasi belajar atau kinerjanya secara unggul. Adanya kegiatan mengatasi masalah belajar ditunjukkan melalui siswa menjadi aktif, bergairah dalam belajar, interaksi di dalam kelas mejadi interaktif dan suasana belajar yang menyenangkan itu dapat terwujud. Secara teoritis, penelitian dapat menambah pengetahuan peneliti mengenai penerapan komunikasi yang efektif.

Adapun rumusan masalah yang hendak dilakukan oleh peneliti adalah: (1) Apa saja masalah dalam proses belajar siswa di SMA Muhammadiyah 2 Yogyakarta?; (2) Bagaimana proses komunikasi guru BK dalam mengatasi siswa bermasalah dalam proses belajar di SMA Muhammadiyah 2 Yogyakarta? 


\section{KAJIAN TEORI}

\section{Pengertian Komunikasi}

Komunikasi yaitu komunikasi atau communication dalam bahasa Inggris berasal dari bahasa Latin yaitu communis yang berarti sama, communico, communication atau communicare yang berati membuat sama (to make common). Istilah pertama (communis) adalah istilah yang paling sering disebut sebagai asal-usul kata komunikasi, yang merupakan akar dari kata Latin lainnya yang mirip komunikasi merupatan suatu pikiran, suatu makna atau suatu pesan yang dianut secara sama (Dedy Mulyana, 2012).

Pada dasarnya penyampaian pesan atau yang digunakan manusia yaitu: komunikasi lisan, tertulis dan non verbal. Beberapa unsur-unsur dalam berkomunikasi, yaitu: komunikator, pesan, penerima pesan, media, dan efek. Komunikasi adalah proses pemindahan pesan dari individu yang mengirimkan kepada penerima pesan. Adanya proses pengiriman dan penerimaan pesan antara dua orang atau lebih dengan beberapa efek dan beberapa umpan balik seketika (Joseph De Vito, 1989. Dikutip oleh: Onong Uchjana Effendy, 2003).

Komunikasi memiliki peranan penting bagi setiap makhluk dalam kehidupannya. Komunikasi dapat menjadi membentuk atau mengembangkan diri dalam bersosialisasi. Melalui komunikasi, manusia dapat mengetahui pribadi dirinya sendiri dan juga orang lain, menjalin persahabatan, mencintai atau mengasihi orang lain, dan sebagainya. Komunikasi merupakan proses dari suatu kegiatan yang berlangsung secara terus-menerus (Tommy Suprapto, 2006).

Terdapat beberapa masalah psikologi yang menjadi latar belakang perlunya layangan BK di sekolah, yaitu: masalah perkembangan individu, masalah perbedaan individu, masalah kebutuhan individu, masalah penyesuaian diri, dan masalah belajar (Tohirin, 2014). Sehingga dalam proses komunikasi guru BK dalam mengatasi siswa bermasalah yang berperan adalah komunikasi antar pribadi.

Komunikasi antar pribadi adalah komunikasi antar individu satu dengan lainnya secara langsung dan bertatap muka. Sehingga dalam komunikasi tersebut dapat menangkap reaksi individu secara langsung, baik secara verbal maupun nonverbal. Adapun bentuk khusus dari komunikasi antar pribadi adalah komunikasi diadik (dyadic communication) yang melibatkan hanya dua orang, seperti suami-isteri, dua sejawat, dua sahabat dekat, guru-murid, dan sebagainya. Komunikasi antar pribadi sebagai komunikasi yang lengkap dan sempurna, sehingga memiliki peran penting selama manusia memiliki emosi untuk berkomunikasi (Deddy Mulyana, 2005).

Hakikat komunikasi antar pribadi adalah: (1) Komunikasi antar 
pribadi merupakan proses sebuah transaksi dan interaksi; (2) Adanya pesan yang diberikan atau disampaikan tidak muncul secara tibatiba, melainkan tercipta dan terkirim oleh pihak yang mengirimkan atau pihak yang memiliki sumber informasi; (3) Komunikasi antar pribadi terjadi secara langsung ataupun tidak langsung; (4) Pesan yang disampaikan secara lisan maupun tertulis; (5) Adanya tatap muka antara individu yang berkomunikasi sehingga dapat langsung menerima respon yang disampaikan (AW Suranto, 2011).

\section{Pengertian Bimbingan dan Konseling}

Berdasarkan Peraturan Menteri Pendidikan dan Kebudayaan No. 111 Tahun 2014 pasal 1 Tentang Bimbingan dan Konseling pada Pendidikan Dasar dan Menengah, yang dimaksud "Bimbingan dan Konseling (BK) adalah upaya sistematis, objektif, logis, dan berkelanjutan serta terprogram yang dilakukan oleh konselor atau guru Bimbingan dan Konseling untuk memfasilitasi perkembangan peserta didik/konseli untuk mencapai kemandirian dalam kehidupannya".

Pengertian BK secara bahasa terdiri atas dua kata, yaitu: bimbingan (guidance) dan konseling (counseling). Bimbingan memiliki arti tuntunan atau pertolongan. Sedangkan konseling ialah proses pertemuan atau hubungan atau relasi antara pembimbing (konselor) dengan klien (siswa). Dalam proses pertemuan atau hubungan timbal balik tersebut terjadi dialog atau pembicaran yang disebut dengan wawancara konseling (Tohirin, 2014).

Pengertian konseling secara bahasa berasal dari bahasa Latin: consiliun yaitu "dengan" dan "bersama", kemudian dirangkai menjadi "menerima" dan "memahami". Dalam bahasa AngloSaxun, istilah konseling ialah "sellan" yaitu "menyerahkan" atau "menyampaikan" (Prayitno dan Erman Amti, 2004).

Bimbingan dan konseling merupakan kegiatan yang integral dan tidak dapat dipisahkan. Perkataan guidance (bimbingan) selalu dirangkaikan dengan konseling sebagai kata majemuk, konseling merupakan salah satu teknik bimbingan sering dikatakan sebagai inti dari keseluruhan pelayanan dan bimbingan.

Guru BK merupakan pemimpin kelompok konseling dan memiliki tanggung jawab terhadap yang terjadi dalam kelompoknya. Guru BK tidak dapat melepaskan tanggung jawab atas berhasil dan tidaknya kelompok yang dipimpinnya. Sehingga guru BK harus memiliki syarat yang berkaitan dengan profesinya, yaitu: pendidikan akademik yang sesuai dengan bidangnya, kepribadian yang menarik, keterampilan dalam berkomunikasi dengan pihak lain dan penggunaan 
teknik-teknik konseling (W.S. Winkel, 1991).

Guru bimbingan dan konseling (BK) pada prinsipnya hanya merupakan perantara atau seseorang yang memberikan alternatif untuk membantu individu dalam menyelesaikan masalahnya, artinya pelaksanaan kegiatan mencegah atau memecahkan masalah-masalah pendidikan yang mungkin sedang atau akan dihadapi, merupakan kegiatan individu yang dibantu itu sendiri.

Tujuan umum BK adalah untuk memandirikan individu. Ada lima ciri pribadi yang mandiri, yaitu: (1) memiliki kemampuan untuk memahami diri sendiri dan lingkungannnya secara tepat dan obyektif; (2) menerima diri sendiri dan lingkungan secara positif dan dinamis; (3) mampu mengambil keputusan secara tepat dan bijaksana; (4) dapat mengarahkan diri sendiri sesuai dengan keputusan yang diambilnya; dan (5) mampu mewujudkan diri sendiri secara optimal (Prayitno dan Erman Amti, 2004).

\section{Permasalahan Siswa}

Permasalahan yang sering dihadapi siswa adalah (Prayitno dan Erman Amti, 2004): prestasi belajar yang rendah dan kurang motivasi belajar; salah paham terhadap orangtua dan guru; pelanggaran terhadap tata tertib yang ada; membolos dan terlambat masuk sekolah; sulit memahami pelajaran; terjadi perselisihan atau bertengkar; sulit untuk menyesuaikan diri; pendiam, pemalu, takut, canggung, kaku, gugup; suka menyendiri dan kurang bergaul. Dari berbagai bentuk masalah yang ada tersebut, siswa kelas XI di SMA Muhammadiyah 2 Yogyakarta menghadapinya. Akan tetapi, yang menjadi fokus penelitian adalah proses belajar siswa saja.

Sementara itu, adanya permasalahan dalam diri siswa karena beberapa faktor, yaitu: faktor kepribadian individu dan faktor lingkungan. Faktor kepribadian terdiri dari: bawaan sejak lahir, baik berhubungan dengan fisik maupun mental; kurangnya pengawasan diri terhadap pengaruh lingkungan yang ada; kurangnya kemampuan dalam menyesuaikan diri terhadap lingkungan; kurangnya nilai-nilai keagamaan atau sukar dalam memilih norma-norma yang baik dan buruk dengan lingkungan (Sufyan S. Wills, 1985). Sedangkan faktor lingkungan ialah: keluarga, sekolah, dan masyarakat.

\section{Proses Belajar}

Belajar adalah suatu kegiatan dengan cara sadar untuk memberikan perubahan yang meliputi: pengetahuan, keterampilan, sikap, dan nilai-nilai (B. Hamzah, 2009). Belajar merupakan perubahan pada tingkah laku karena adanya pengulangan yang bersifat latihan dan pengalaman (Oemar Hamalik, 2005). Selain itu, belajar juga merupakan aktivitas untuk perubahan secara permanen sebagai 
akibat dari upaya yang dilakukan (A. Suhaenah Suparno, 2001).

Adapun proses dalam pembelajaran yang diperlukan yaitu: (1) Peserta didik memahami dan menghayati bahwa pengetahuan yang diperoleh berasal dari lingkungannya;

(2) Upaya peserta didik menghayati proses belajar dengan melakukan sesuatu yang memiliki makna; (3) Memungkinkan lahirnya manusiamanusia yang terdidik dan mandiri; (4) Melakukan pendekatan melalui penerapan ilmu pengetahuan, sehingga peserta didik menemukan kebahagiaan dalam belajar (B. Hamzah, 2009).

Pengajaran merupakan suatu sistem atau keseluruhan dari komponen-komponen yang berinterelasi dan berinteraksi antara satu dengan lainnya (Oemar Hamalik, 2005). Komponen dalam pembelajaran meliputi: tujuan pendidikan dan pengajaran, peserta didik atau siswa, tenaga kependidikan, rencana pengajaran, strategi pembelajaran, media pengajaran, evaluasi pembelajaran.

\section{METODE PENELITIAN}

Penelitian ini menggunakan metode penelitian kualitatif yang disampaikan dengan deskriptif. Fokus dalam penelitian pada proses komunikasi antara Guru BK dan siswa dalam mengatasi masalah dalam proses belajar di SMA Muhammadiyah 2 Yogyakarta yang dilakukan di dalam kelas atau bimbingan konseling secara klasikal dan yang mengandung unsur komunikasi, yaitu proses dan pola komunikasi yang digunakan Guru BK dalam memberikan layanan bimbingan konseling klasikal tentang mengatasi permasalahan proses belajar. Pada saat Guru BK melakukan kegiatan bimbingan konseling klasikal dengan siswa kelas XI dalam pelaksanaannya merupakan bagian dari proses dan pola komunikasi.

Populasi yang digunakan dalam penelitian ini yaitu siswa kelas XI SMA Muhammadiyah 2 Yogyakarta tahun pelajaran 2017/2018. Adapun jumlah siswa sebanyak 317 siswa. Adapun alasan peneliti mengambil subyek dan lokasi penelitian didasarkan pada pertimbangan: (1) Siswa kelas XI pada umumnya telah mengetahui proses belajarnya, hal ini karena dipengaruhi dengan padatnya kurikulum yang dihadapi pada masa SMA; (2) Pihak sekolah memiliki antusiasisme yang tinggi untuk memberikan pelayanan terhadap anak didiknya, sehingga akan mempermudah peneliti untuk melakukan penelitian sekaligus pendekatan kepada para siswa tanpa harus dibatasi oleh waktu dan prosedur dari sekolah yang rumit; (3) Subjek yang akan diteliti memiliki kesesuaian dengan apa yang telah dengan ciri dari populasi penelitian (siswa SMA dan memiliki komunikasi dengan guru BK dalam mengatasi masalah proses belajar).

Peneliti menggunakan teknik sampling yang bersifat purposive 
sampling, yaitu peneliti memilih informasi yang dapat mengetahui secara mendalam tentang informasi dan data-data yang diperoleh atau diperlukan. Peneliti juga menggunakan 2 sumber data yaitu sumber data primer dan sekunder. Metode pengumpulan data yang digunakan dalam penelitian ini, yaitu: tanya jawab (interview), pengamatan dan pencatatan (observasi), dan dokumentasi.

\section{HASIL DAN PEMBAHASAN}

Proses belajar merupakan bagian dari pembelajaran siswa dalam mengikuti kegiatan belajar mengajar (KBM) antara guru dengan siswa. Belajar sebagai perubahan tingkah laku akan berlangsung lama dan merupakan proses yang pelik dan kompleks bahkan sebagai proses ruang hampa. Kadang-kadang proses belajar siswa kelas XI SMA Muhammadiyah 2 Yogyakarta tidak dapat mencapai hasil yang maksimal disebabkan oleh tidak adanya kekuatan dan motivasi yang mendorongnya untuk belajar.

Oleh karena itu, kehadiran kegiatan bimbingan konseling dalam membangkitkan motivasi dan memelihara motivasi belajar peserta didik sangat diperlukan. Sehingga, dalam proses belajar peran guru BK yang dulunya hanya dilakukan di luar kelas, seperti bimbingan konseling induvidu dan bimbingan konseling kelompok. Maka sejak saat itu bimbingan konseling dilakukan di dalam kelas atau klasikal seperti mata pelajaran yang lain.

Metode dan kreativitas guru BK dalam memberikan bimbingannya tidak dapat dilepaskan dari sarana dan prasarana yang lengkap dan mendukung proses pembelajaran di SMA Muhammadiyah 2 Yogyakarta. Sehingga dalam proses KBM guru BK menggunakan media pembelajaran yang kreatif dan menarik.

Proses komunikasi adalah bagaimana sang komunikator menyampaikan pesan kepada komunikannya, sehingga dapat menciptakan suatu persamaan makna antara komunikan dengan komunikatornya. Proses komunikasi ini bertujuan untuk menciptakan komunikasi yang efektif (sesuai dengan tujuan komunikasi pada umumnya).

Proses BK klasikal pada hakikatnya adalah proses komunikasi, penyampaian pesan dari pengantar ke penerima. Pesan yang disampaikan berupa isi atau ajaran yang dituangkan ke dalam simbol-simbol komunikasi, baik verbal (kata-kata dan tulisan) maupun nonverbal. Proses ini dinamakan encoding. Penafsiran simbol-simbol komunikasi tersebut oleh oleh siswa dinamakan decoding.

Beberapa tahap proses dan metode yang digunakan dalam bimbingan konseling klasikal mengatasi masalah siswa dalam proses belajar di SMA Muhammadiyah 2 Yogyakarta diantaranya: pertama, tahap persiapan, dengan: 
Mengidentifikasi kebutuhan atau masalah siswa, dalam hal ini guru BK bertugas menyebarkan angket yang berisi tentang masalah-masalah yang dialami siswa. Kegiatan dilakukan 3 bulan sekali di SMA Muhammadiyah 2 Yogyakarta; (2) Menetapkan tujuan atau kompetensi yang akan dicapai; (3) Menetapkan teknik dan media yang akan digunakan dalam bimbingan konseling klasikal tentang proses belajar.

Kedua, tahap pembentukan, yaitu: (1) Pembentukan awal; (2) Pembentukan inti, adapun metode yang digunakan ialah: metode ceramah, tanya jawab, demonstrasi, dan psikodrama. Ketiga, tahap evaluasi, yaitu memberikan penilaian terhadap siswa. Evaluasi dimaksudkan untuk melihat keberhasilan siswa dalam menerima dan memahami materi bimbingan yang disampaikan, baik melalui metode ceramah, diskusi, demonstrasi maupun psikodrama. Biasanya guru memberikan soal-soal simulasi untuk melihat pemahaman siswa.

Melalui layanan BK, guru BK dapat memberi penyuluhan agar siswa berkembang secara optimal dalam proses pengembangan bakat dan belajar. Fungsi layanan BK membantu siswa yang bermasalah dalam proses belajar, berupa penyelesaian masalah secara konseling. Guru BK juga mempunyai agenda kunjungan rumah, sehingga dapat bertemu dengan orang tua siswa untuk memaksimalkan pelayanan konseling. Selain itu, memiliki program kelas yang disebut layanan klasikal (informasi memberikan materi dan motivasi dalam belajar siswa). Adanya kerja sama dengan guru kelas, guru mata pelajaran dan wakil kepala sekolah bidang kesiswaan untuk membimbing siswa yang bermasalah dalam belajar.

Faktor penghambat dari layanan BK yang dilakukan guru BK yaitu masalah motivasi misal: memiliki potensi bakat bagus tetapi motivasi dalam belajar kurang jadi kesadaran siswa harus dipacu melalui bimbingan konseling. Selain itu, faktor pendukung dari layanan BK yaitu orang tua harus memberikan perhatian. Seringnya yang dihadapi siswa di sini adalah masalah broken home atau persoalan keluarga, jadi kesadaran anak yang harus dipantau, mereka suka bermain daripada belajar. Masalh ini seringkali muncul karena longgarnya orang tua dalam mengontrol, mengawasi anak ketika bermain.

Komunikasi yang dilakukan oleh guru dan siswa merupakan pembahasan secara pribadi yang dilakukan oleh guru terhadap salah satu siswa yang memerlukan perhatian dan nasehat dalam mengatasi masalah yang dihadapi oleh siswa. Misalnya masalah pribadi, masalah dengan teman, maupun masalah akademis. Respon yang dilakukan guru BK sebagai arahan dan langkah-langkah dalam mengatasi masalah yang hadapi agar siswa mampu menyelesaikan masalah dan berkomunikasi seperti 
biasa dengan teman-teman yang lain, dan mampu menerima materi-materi pelajaran yang disampaikan oleh guru mata pelajaran di dalam kelas.

Efektivitas komunikasi guru dan siswa dalam mengatasi masalah proses belajar dengan dalam BK di SMA Muhammadiyah 2 Yogyakarta telah berjalan efektif dan mencapai tujuan yang diharapkan yakni terciptanya lingkungan sekolah yang kondusif untuk belajar. Hal ini terlihat karena secara garis besar siswa merasa mempunyai hubungan yang baik dengan guru BK.

\section{KESIMPULAN}

Berdasarkan dari penelitian dan penyajian data beserta analisisnya kesimpulan sebagai berikut:

1. Masalah dalam proses belajar siswa di SMA Muhammadiyah 2 Yogyakarta seperti: malas mengikuti pelajaran, tidak dapat konsentrasi saat mengikuti pelajaran, tertidur saat guru mata pelajaran menjelaskan materi, masalah keluarga, masalah antar teman, dan masalah yang lainnya. Melalui layanan fungsi layanan BK dalam proses belajar yaitu: (a) Berusaha membantu siswa yang bermasalah dalam proses belajar dengan cara dipanggil untuk penyelesaian masalah secara konseling; (b) Melakukan agenda kunjungan rumah, sehingga ketika kunjungan ke rumah dapat bertemu dengan orang tua siswa untuk memaksimalkan pelayanan konseling; (c) Layanan klasikal dengan informasi, materi, dan motivasi dalam belajar siswa; (d) Bekerjasama dengan wali kelas, guru bidang studi dan wakil kepala sekolah bidang kesiswaan untuk membimbing siswa yang bermasalah dalam belajar; (e) Mendiagnosis siswa dengan cara mengumpulkan informasi tentang kepribadian siswa.

2. Proses komunikasi guru BK dalam mengatasi siswa bermasalah dalam proses belajar di SMA Muhammadiyah 2 Yogyakarta. Adapun beberapa tahap proses dan metode yang digunakan dalam bimbingan konseling klasikal menangani masalah dalam proses belaja di SMA Muhammadiyah 2 Yogyakarta yaitu: tahap persiapan, terdiri dari: pembentukan awal (metode pembiasaan) dan pembentukan inti (metode ceramah, metode tanya jawab, metode demonstrasi dan metode psikodrama); tahap pembentukan; dan tahap evaluasi.

\section{DAFTAR PUSTAKA}

Depdikbud. 2003. Undang-undang No. 20 Tahun 2003 Tentang Sistem Pendidikan Nasional (Sisdiknas). Yogyakarta: Media Wacana Press.

Effendy, Onong. 1993. Ilmu Teori dan Filsafat Komunikasi. Bandung: PT. Citra Aditya Bhakti. 
Hamalik, Oemar. 2005. Kurikulum dan Pembelajaran. Jakarta: Bumi Aksara.

Hamzah, B. 2009. Model Pembelajaran: Menciptakan Proses Belajar Mengajar yang Kreatif dan Efektif. Jakarta: Bumi Aksara.

Liliweri, Alo. 1997. Komunikasi Antar Pribadi. Bandung: PT. Citra Aditya.

Mulyana, Dedy. 2012. lmu Komunikasi Suatu Pengantar. Bandung: PT. Remaja Rosdakarya.

Prayitno dan Amti, Erman. 2004. Dasar-daras Bimbingan dan Konseling. Jakarta: Rineka Cipta.

Suparno, A. Suhaenah. 2001. Membangun Kompetensi Belajar. Jakarta: Direktorat Jendral Pendidikan Tinggi Departemen Pendidikan Nasional.

Suprapto, Tommy. 2006. Pengantar Teori Komunikasi. Yogyakarta: Media Pressindo.

Suranto, AW. 2011. Komunikasi Interpersonal. Yogyakarta: Graha Ilmu.

Tohirin. 2007. Bimbingan Konseling di Sekolah dan Madrasah. Jakarta: Raja. Grafindo Persada.

Vito, Joseph De. 1989. The Interpersonal Communication
Book. Harper and Row. New York.

Wills, Sufyan S. 1985. Kenakalan Remaja. Jakarta: Bulan Bintang.

Winkel, W.S. 1991. Bimbingan Dan Konseling Di Institusi Pendidikan. Jakarta: PT. Grasindo. 